Received: 08-12-2019

(Date-Month-Year)
Revised: 12-01-2020

(Date-Month-Year)
Published: 20-04-2020

(Date-Month-Year)

\title{
ANALISIS PEMECAHAN MASALAH GEOMETRI BERDASARKAN TINGKAT BERPIKIR TEORI VAN HIELE DAN GENDER
}

\author{
Marlinda Indah Eka Budiarti ${ }^{1}$, Faisal Eka Mahendra ${ }^{2}$ \\ ${ }^{1,2}$ Pendidikan Matematika, Universitas Muhammadiyah Sorong, Indonesia \\ 1indah.eka43@gmail.com \\ ${ }^{2}$ faisalekamahendra132@gmail.com
}

\begin{abstract}
Abstrak: Sehubungan dengan kesulitan dalam belajar geometri maka guru sangat berperan penting dan aktif untuk menciptakan peserta didik yang memiliki kemampuan pemecahan masalah yang baik. Guru juga harus menguji tingkat berpikir geometri peserta didik berdasarkan teori Van Hiele untuk mengetahui sejauh mana peserta didik memahami materi geometri sehingga guru dapat mengatasi kesulitan peserta didik dalam belajar geometri. Penelitian ini dirancang untuk mengeksplorasi dan mendeskripsikan proses pemecahan masalah geometri berdasarkan teori Van Hiele. Oleh karena itu jenis penelitian yang digunakan dalam penelitian ini adalah deskriptif eksploratif. Pendekatan yang digunakan dalam penelitian ini adalah pendekatan kualitatif. Subjek penelitian ini dibatasi pada peserta didik Universitas Muhammadiyah Sorong yang mencapai tingkat visualisasi, analisis dan deduksi informal dengan yang akan dianalisis berdasarkan gendernya. Data dan sumber data dalam penelitian ini adalah: 1) tes geometri Van Hiele; 2) tes pemecahan masalah; 3) wawancara. Adapun hasil dari penelitian ini adalah: 1) Pada tingkat berpikir visualisasi laki-laki hanya adalah dengan mengidentifikasi masalah dan menentukan tujuan dengan menggunakan bahasa soal. Sedangkan pada tingkat visualisasi perempuan, sampai pada tahap menentukan tujuan; 2) tingkat berpikir analisis laki-laki mampu melalui kelima langkah pemecahan masalah menggunakan bahasanya sendiri namun kurang sistematis. Sedangkan tingkat berfikir analisis perempuan mampu melalui kelima langkah pemecahan masalah dengan sistematis; 3) tingkat berfikir deduksi informal laki-laki adalah melalui kelima langkah pemecahan masalah dengan sistematis dan menggunakan bahasanya sendiri. Sedangkan tingkat berfikir deduksi informal perempuan adalah mampu melalui kelima langkah pemecahan masalah dengan sistematis serta menjelaskan menggunakan bahasanya sendiri.
\end{abstract}

Kata Kunci: Pemecahan Masalah; Van Hiele; Gender

\begin{abstract}
Due to difficulties in learning geometry, the teacher plays an important and active role in creating students who have good problem solving skills. The teacher also has to test the level of geometrical thinking of students based on Van Hiele's theory to find out the students understanding about geometry material, so the teacher can overcome the difficulties of students in learning geometry. This research is designed to explore and describe the process of geometry problem solving based on Van Hiele's theory. Therefore this research used descriptive exploratory. It used qualitative approach. The subject of this research is limited to University of Muhammadiyah Sorong students which obtained the level of visualization, analysis, informal deductive and will be analyzed based on the gender. Data of this research is 1) Geometry Van Hiele Test; 2) Problem Solving Test; 3) Interview. The conclusion of this research is: 1) At the level of male visualization thinking is to identify problem and determine goal using language problem. While at the level of women visualization, it reached on determining goal, ; 2) the level of male analysis thinking is able to pass five steps in problem solving by using own language but are less systematic. While level of female analysis thinking is able to pass five steps in problem solving systematically; 3 ) level of male deductive formal thinking is to pass five steps problem solving systematically and using own language. While level of female deductive formal thinking is able to pass five steps problem solving systematically and explaining by using own language.
\end{abstract}

Keywords: Problem Solving; Van Hiele; Gender 


\section{Pendahuluan}

Salah satu hal terpenting ialah pemecahan masalah (Al-Migdady, 2014; Aydoğdu \& Keşan, 2014; NCTM, 2010). Cara tepat dalam menyelesaikan masalah matematika ialah kecakapan berpikir dalam memahami konsep-konsep matematika (Saragih \& Habeahah, 2014; Muhassanah, 2014). Fakta dilapangan mengemukakan banyak mahasiswa yang memiliki kesulitan dalam memecahkan masalah geometri yang seharusnya tujuan dari belajar geometri ialah dapat memecahkan masalah geometri yang baik (Muhassanah, 2014;Abu \& Abidin, 2013; Özerem, 2013).

Selain itu, data dari Balitbang (2012) mengemukakan untuk kompetensi geometri peserta didik SMP dan SMA keserapan ujian nasional pada tahun 2012 berada pada tingkat terendah dari kompetensi lainnya. Seharusnya guru dapat berperan aktif dalam menciptakan kemampuan dalam memecahkan masalah yang baik bagi mahasiswa. Sehingga dapat mempermudah mengatasi kesulitan dalam mempelajari geometri. Teori Van Hiele adalah salah satu sarana untuk mengetahui pemahaman materi geometri. Sehingga dengan menguji tingkat berpikir geometri, guru dapat mengatasi kesulitan peserta didik dalam mempelajari geometri.

Hasil penelitian dari beberapa penelitian terdahulu pada teori Van Hiele menyatakan Pinar (2014) menunjukkan bahwa tingkat berpikir geometri peserta didik kelas IV, V, VI, dan VII berdasarkan teori Van Hiele masih rendah. Khoiriyah, dkk (2014) mengemukakan bahwa tingkat berpikir geometri peserta didik SMA berada pada tingkat analisis. Alex \& Mammen (2014) menyatakan bahwa mayoritas peserta didik kelas X SMA berada pada tingkat visualisasi.

$\begin{array}{rcr}\text { Banyak } & \begin{array}{c}\text { faktor-faktor } \\ \text { seseoang }\end{array} & \begin{array}{r}\text { yang } \\ \text { dalam }\end{array}\end{array}$

menyelesaikan pemecahan masalah, diantaranya adalah gender ( Zhu, 2007; Afrida dkk, 2019). Hal ini ditunjukkan dengan adanya penelitian yang menunjukkan adanya perbedaan proses berpikir dalam pemecahan masalah berdasarkan gender dan tipe kepribadian introvert dan ekstrovert (Hasanah. M, 2013).

Berdasarkan latar belakang tersebut untuk meningkatkan kemampuan pemecahan masalah geometri maka guru perlu melihat proses pemecahan masalah geometri untuk mengetahui sejauh mana peserta didik memahami materi geometri. Sehingga penulis tertarik untuk meneliti proses pemecahan masalah geometri berdasarkan teori Van Hiele dan gender, pembeda penelitian ini dengan penelitian sebelumnya, yaitu pengambilan sampel pada Universitas.

\section{Metode Penelitian}

Penelitian ini dirancang untuk mengeksplorasi dan mendeskripsikan proses pemecahan masalah geometri berdasarkan teori Van Hiele. Oleh karena itu jenis penelitian yang digunakan dalam penelitian ini adalah deskriptif eksploratif. Pendekatan yang digunakan dalam penelitian ini adalah pendekatan kualitatif.

Subjek penelitian ini dibatasi pada peserta didik Universitas Muhammadiyah Sorong yang mencapai tingkat visualisasi, analisis dan deduksi informal dengan yang akan dianalisis berdasarkan gendernya, yaitu lai-laki dan perempuan. Subjek tingkat deduksi formal dan rigor tidak bisa diungkap dikarenakan subjek tidak ada yang mencapai tingkat tersebut. Cara pengambilan subjek penelitian dalam penelitian ini yaitu Universitas Muhammadiyah Sorong dites mengenai tingkat geometri berdasarkan teori Van Hiele diperoleh tingkat visualisasi, analisis dan deduksi informal. Kemudian setelah tingkat Van Hiele yang 
diinginkan, Selanjutnya, setiap tingkat diambil dua peserta didik yang memiliki skor relatif sama serta yang dapat berkomunikasi dengan baik. Sehingga seluruh subjek penelitian terdapat enam peserta didik.

Data yang diperoleh dalam penelitian ini berupa: 1) data hasil tes geometri Van Hiele diperoleh dari tes geometri Van Hiele yang berupa pilihan ganda yang diberikan kepada peserta didik SMA; 2) data proses pemecahan masalah subjek penelitian diperoleh dari tes tertulis dan wawancara setelah subjek menyelesaikan masalah geometri. Data ini digunakan untuk menjawab masalah penelitian.

Adapun teknik pengumpulan data yang digunakan dalam penelitian ini adalah triangulasi sumber (Sugiyono, 2016).

1. Tes soal geometri Van Hiele

Tes soal geometri Van Hiele digunakan untuk menilai tingkat berpikir pada konsep yang berbeda.

Instrumen penelitian tes soal geometri Van Hiele merupakan lembar pertanyaan tes sebanyak 25 soal pilihan ganda dengan lima pilihan berdasarkan tingkat geometri Van Hiele. Tes soal geometri Van Hiele merupakan tes soal yang dikembangkan oleh Usiskin. Setiap tingkat geometri Van Hiele terdiri dari lima soal. Namun untuk nomor urut soal dalam penelitian ini di acak agar peserta didik mengerjakan soal dengan tingkat yang bervariasi. Apabila tingkat kesukaran soal Van Hiele semakin naik maka memungkinkan peserta didik tidak membaca soal selanjutnya. Berikut, ialah level urutan tes soal geometri Van Hieleseperti pada Tabel 1.
Tabel 1. Level urutan soal tes geometri Van Hiele

\begin{tabular}{cc}
\multicolumn{2}{c}{ Van Hiele } \\
\hline Level & Nomor Soal \\
\hline 1 & $1,6,11,16,21$ \\
\hline 2 & $2,7,12,17,22$ \\
\hline 3 & $3,8,13,18,23$ \\
\hline 4 & $4,9,14,19,24$ \\
\hline 5 & $5,10,15,20,25$ \\
\hline
\end{tabular}

Konten tes soal geometri Van Hielediambil dari topik-topik seperti konsep geometri dasar dan klasifikasi serta sifat segitiga dan segi empat. Topik-topik tersebut membentuk dasar untuk ruang dan bentuk pada kelas X ke atas.

2. Tes soal

Tes soal digunakan untuk mengetahui proses dalam memecahkan masalah berdasarkan indikator. Tes soal terdiri dari dua soal uraian tentang geometri yang diambil dari soal olimpiade matematika tingkat nasional yang telah divalidasi oleh dua orang ahli matematika dan satu orang ahli bahasa Indonesia. Mencari data yang realiabrel diperlukan tes soal minimal sebanyak dua kali dengan tingkat kesulitan yang sama. 
Tabel 2. Indikator Proses Pemecahan Masalah IDEAL Berdasarkan Teori Van Hiele

Tingkat

berpikir Van Hiele

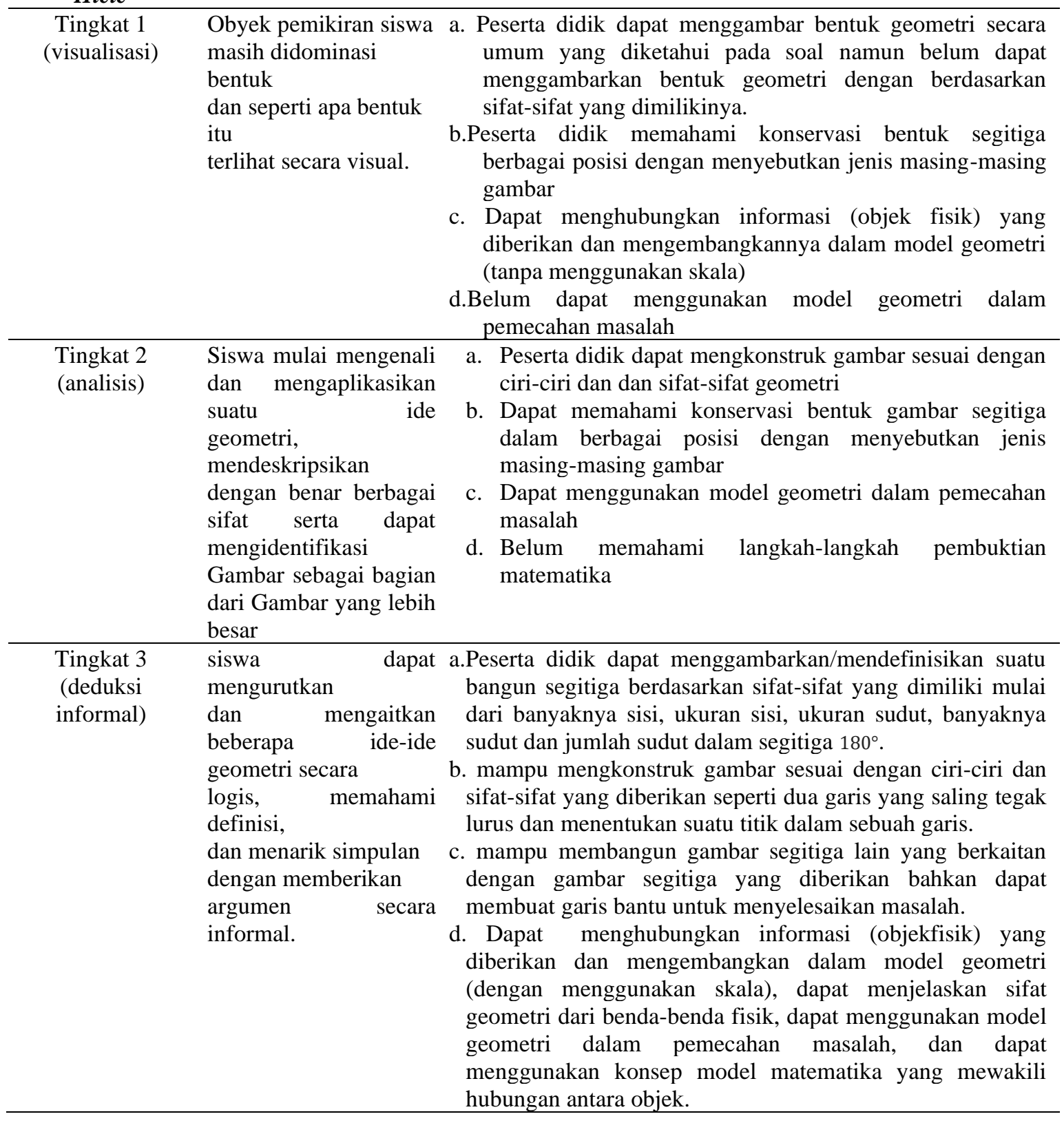


3. Wawancara

Wawancara berupa garis besar pertanyaan proses pemecahan masalah geometri yang disesuaikan dengan model soal tes yang digunakan.

Teknik analisis data yang digunakan ialah data kualitatif yang mengutip konsep oleh Miles and Huberman. Aktivitas dalam analisis data yaitu:

1. Data tes berpikir geometri berdasarkan Van Hiele

Aktivitas dalam analisis data tes geometri Van Hiele diantaranya yaitu hasil tes geometri Van Hiele dikoreksi kemudian dikelompokkan berdasarkan tingkatan Van Hiele. Dalam penelitian ini diperoleh subjek penelitian yang mencapai tingkat visualisasi, analisis dan deduksi informal. Setiap tingkat visualisasi, analisis dan deduksi informal diambil dua peserta didik yang kemudian dijadikan subjek penelitian.

2. Data tes pemecahan masalah geometri

a. Reduksi data

Aktivitas ini mengarah
pada proses menyeleksi,
meresume serta menitik beratkan
pada hal-hal yang penting.

Tahap reduksi data dalam penelitian ini meliputi:

a) Mengoreksi hasil soal tes subjek penelitian

b) Hasil tes soal dikelompokkan berdasarkan tingkat geometri Van Hile.

c) Data proses pemecahan masalah pertama dan kedua dirangkum dan difokuskan pada hal-hal yang penting

b. Penyajian data

Data yang diperoleh disajikan dalam bentuk teks yang bersifat naratif serta dalam bentuk Gambar untuk mempermudah mengetahui

perbedaan proses pemecahan masalah IDEAL berdasarkan tingkat geometri berdasarkan teori Van Hiele.

c. Penarikan simpulan

Dari data yang diperoleh dan disajikan maka dapat ditarik simpulan proses pemecahan masalah berdasarkan tingkat teori Van Hiele dan Gender.

\section{Prosedur Penelitian}

Kegiatan penelitian dilakukan dalam tiga tahapan kegiatan pokok, yaitu:

a. Tahap persiapan

Aktivitas yang dilakukan pada tahap persiapan yaitu: 1) meminta ijin ke pihak kampus untuk melakukan penelitian; 2) menanyakan ke pada pihak dosen mata kuliah geometri tentang sejauh mana peserta didik SMA mempelajari geometri serta hal-hal lain yang berkaitan dengan penelitian; 3) peneliti mengkaji teori geometri Van Hiele dan pemecahan masalah IDEAL; 4) menyiapkan instrumen geometri Van Hiele dan soal pemecahan masalah geometri, dan; 5) melakukan administrasi penelitian

b. Tahap pelaksanaan penelitian

Aktivitas yang dilakukan pada tahap pelaksanaan penelitian yaitu: 1) tes geometri Van Hiele dilakukan melalui pemberian soal tes geometri Van Hiele; 2) tes pemecahan masalah yang dilakukan oleh subjek penelitian; 3) menganalisis tes menggunakan indikator pemecahan masalah berdasarkan tingkat berpikir geometri Van Hiele yang kemudian di perkuat adanya wawancara dari responden. 
c. Tahap pelaporan

Tahap terakhir yaitu tahap pelaporan. Kegiatan yang dilakukan pada tahap ini yaitu mengolah dan menganalisis data hasil penelitian yang kemudian dilanjutkan menyusun laporan penelitian.

\section{Hasil dan Pembahasan}

Berdasarkan hasil penelitian yang telah dilakukan, maka disusun Tabel 3.

Tabel 3. Analisis Tingkat Van Hiele berdasarkan Penyelesaian Mahasiswa

\begin{tabular}{|c|c|c|c|c|c|}
\hline \multirow{3}{*}{$\begin{array}{l}\text { Tingkat } \\
\text { Visualisasi } \\
\text { laki-laki }\end{array}$} & \multicolumn{5}{|c|}{ Tahap } \\
\hline & 1 & 2 & 3 & 4 & 5 \\
\hline & $\begin{array}{l}\text { Mampu } \\
\text { menidentifikasi } \\
\text { masalah }\end{array}$ & $\begin{array}{l}\text { Mampu } \\
\text { menentukan } \\
\text { tujuan dengan } \\
\text { kata-kata sendiri } \\
\text { tapi tidak } \\
\text { sistematis }\end{array}$ & $\begin{array}{l}\text { Belum mampu } \\
\text { mencari strategi } \\
\text { yang mungkin }\end{array}$ & $\begin{array}{l}\text { Belum mampu } \\
\text { dalam } \\
\text { melaksanakan } \\
\text { strategi }\end{array}$ & $\begin{array}{l}\text { Belum } \\
\text { mampu } \\
\text { dalam } \\
\text { mengkaji } \\
\text { kembali dan } \\
\text { mengevalusi } \\
\text { pengaruhnya }\end{array}$ \\
\hline $\begin{array}{l}\text { Visualisasi } \\
\text { perempuan }\end{array}$ & $\begin{array}{l}\text { Mampu } \\
\text { menidentifikasi } \\
\text { masalah }\end{array}$ & $\begin{array}{l}\text { Mampu } \\
\text { menentukan } \\
\text { tujuan dengan } \\
\text { kata-kata sendiri } \\
\text { serta sistematis }\end{array}$ & $\begin{array}{l}\text { Belum mampu } \\
\text { mencari strategi } \\
\text { yang mungkin }\end{array}$ & $\begin{array}{l}\text { Belum mampu } \\
\text { dalam } \\
\text { melaksanakan } \\
\text { strategi }\end{array}$ & $\begin{array}{l}\text { Belum } \\
\text { mampu } \\
\text { dalam } \\
\text { mengkaji } \\
\text { kembali dan } \\
\text { mengevalusi } \\
\text { pengaruhnya }\end{array}$ \\
\hline $\begin{array}{l}\text { Analis laki- } \\
\text { laki }\end{array}$ & $\begin{array}{l}\text { Mampu } \\
\text { menidentifikasi } \\
\text { masalah }\end{array}$ & $\begin{array}{l}\text { Mampu } \\
\text { menentukan } \\
\text { tujuan dengan } \\
\text { kata-kata sendiri }\end{array}$ & $\begin{array}{l}\text { Mampu mencari } \\
\text { strategi yang } \\
\text { mungkin }\end{array}$ & $\begin{array}{l}\text { Mampu dalam } \\
\text { melaksanakan } \\
\text { strategi }\end{array}$ & $\begin{array}{l}\text { Belum } \\
\text { mampu } \\
\text { dalam } \\
\text { mengkaji } \\
\text { kembali dan } \\
\text { mengevalusi } \\
\text { pengaruhnya }\end{array}$ \\
\hline $\begin{array}{l}\text { Analisis } \\
\text { perempuan }\end{array}$ & $\begin{array}{l}\text { Mampu } \\
\text { menidentifikasi } \\
\text { masalah }\end{array}$ & $\begin{array}{l}\text { Mampu } \\
\text { menentukan } \\
\text { tujuan dengan } \\
\text { kata-kata sendiri }\end{array}$ & $\begin{array}{lr}\text { Mampu mencari } \\
\text { strategi yang } \\
\text { mungkin }\end{array}$ & $\begin{array}{l}\text { Mampu dalam } \\
\text { melaksanakan } \\
\text { strategi }\end{array}$ & $\begin{array}{l}\text { Belum } \\
\text { mampu } \\
\text { dalam } \\
\text { mengkaji } \\
\text { kembali dan } \\
\text { mengevalusi } \\
\text { pengaruhnya }\end{array}$ \\
\hline $\begin{array}{l}\text { Deduksi } \\
\text { informal } \\
\text { laki-laki }\end{array}$ & $\begin{array}{l}\text { Mampu } \\
\text { menidentifikasi } \\
\text { masalah }\end{array}$ & $\begin{array}{l}\text { Mampu } \\
\text { menentukan } \\
\text { tujuan dengan } \\
\text { kata-kata sendiri }\end{array}$ & $\begin{array}{l}\text { Mampu mencari } \\
\text { strategi yang } \\
\text { mungkin }\end{array}$ & $\begin{array}{l}\text { Mampu dalam } \\
\text { melaksanakan } \\
\text { strategi }\end{array}$ & $\begin{array}{l}\text { Mampu dalam } \\
\text { mengkaji } \\
\text { kembali dan } \\
\text { mengevalusi } \\
\text { pengaruhnya }\end{array}$ \\
\hline $\begin{array}{l}\text { Deduksi } \\
\text { informal } \\
\text { perempuan }\end{array}$ & $\begin{array}{l}\text { Mampu } \\
\text { menidentifikasi } \\
\text { masalah }\end{array}$ & $\begin{array}{l}\text { Mampu } \\
\text { menentukan } \\
\text { tujuan dengan } \\
\text { kata-kata sendiri }\end{array}$ & $\begin{array}{lr}\text { Mampu mencari } \\
\text { strategi yang } \\
\text { mungkin }\end{array}$ & $\begin{array}{l}\text { Mampu dalam } \\
\text { melaksanakan } \\
\text { strategi }\end{array}$ & $\begin{array}{l}\text { Mampu } \\
\text { dalam } \\
\text { mengkaji } \\
\text { kembali dan } \\
\text { mengevalusi } \\
\text { pengaruhnya }\end{array}$ \\
\hline
\end{tabular}

Berdasarkan Tabel 3 Analisis Tingkat Van Hele berdasarkan penyelesaian mahasiswa dalam memecahan masalah dapat disimpulkan bahwa visualisasi laki-laki mampu hingga tahap 2 dari pemecahan masalah. Hal ini diperkuat dari hasil wawancara bahwa peserta didik belum mampu untuk 
mencari strategi yang mungkin karena kurangnya pengetahuan mengenai dalil, postulat yang di pahami. Seangkan dari segi visualisasi perempuan, telah mampu sampai pada tahap ke 4 dari tahap pemecahan masalah.

Hasil penelitian yang telah diuraikan di atas menunjukkan bahwa proses pemecahan masalah geometri yang dimiliki subjek berdasarkan tingkat berpikir Van Hiele berbeda-beda. Subjek yang mencapai tingkat visualisasi hanya bisa menyelesaikan pada langkah mengidentifikasi masalah dengan membuat bangun secara umum dan menentukan tujuan dengan menggunakan bahasa pada soal serta kesalahaan pada penulisan sudut. Hal ini sesuai dengan Noriza, dkk (2015) yang menyatakan bahwa peserta didik pada tingkat visualisasi tidak dapat membuat model matematika, hal ini terlihat dari kemampuan untuk membuat sketsa berdasarkan unsur-unsur yang sudah dikenal. Peserta didik membuat bentuk geometri berdasarkan penampilan fisik secara keseluruhan (Muhassanah, dkk, 2014). Selain itu peserta didik tidak mampu merencanakan dengan baik dalam memecahkan masalah hal ini dikarenakan peserta didik dalam mengidentifikasi bentuk geometri secara keseluruhan yang mengakhibatkan tidak dapat menentukan strategi yang digunakan untuk memecahkan masalah.

Berdasarkan gendernya, visualisasi laki-laki lebih monoton dalam menjelaskan dari pada visualisasi perempuan. Hal ini terlihat pada saat peserta didik menjelaskan strategi, akan tetapi tidak mampu untuk menuliskan secara detail. Hal ini sesuai dengan penelitian (Walia: 2012) yang mengemukakan bahwa secara umum, jenis kelamin tidak mempengaruhi pencapain dalam matematika dan kreativitas matematika, namun ditemukan peserta didik perempuan lebih baik daripada anak laki-laki dalam satu dimensi fleksibelitas.

Subjek berada pada tahap tingkat analisis, pada tahapan pemecahan masalah matetisnya sudah berada pada tahap kelima, yang mampu melewati tahapan-tahapan pemecahan masalah, akan tetapi masih kurang sistematis dalam penulisannya. Hal ini terlihat pada pencapaian tahapan tingkat analisis pemecahan masalah tetapi salah dalam menuliskan sudut. Hal ini sejalan dengan penelitian Noriza,dkk (2015) menyatakan peserta didik yang mampu mencapai tahapan analisis, sehingga mampu mengidentifikasi unsur-unsur yang ditanya dan diketahui, serta mengembangkan model matematika walau belum lengkap. Muhassanah, dkk (2014) mengungkapkan bahwa kekurang mampuan siswa dalam menyebutkan rumus, menandakan bahwa keberadaan siswa pada tahap analisis.

Sedangkan subjek yang mencapai tingkat deduksi informal dapat menentukan kelima langkah pemechan masalah dengan sistematis dan menggunakan bahasanya sendiri akan tetapi masih ada beberapa kekeliruan dalam penulisan sudut. Sesuai dengan hasil penelitian Noriza, dkk (2015) menyatakan bahwa peserta didik tingkat deduksi informal dapat mengidentifikasi unsur-unsur yang diketahui dan ditanyakan. Peserta didik mampu membangun sebuah model matematika dengan benar, hal ini terlihat dari kemampuan peserta didik pada deduksi informal untuk membuat sketsa geometri yang dilengkapi dengan unsur-unsur yang diketahui. Langkah melaksanakan rencana tersebut, para peserta didik dapat menyelesaikan masalah karena dapat merancang pemecahan dengan benar. Peserta didik dapat menulis simpulan akhir dari pemecahan masalah.

Berdasarkan gendernya pun terlihat pada tingkat deduksi informal 
perempuan lebih rinci menuliskan pengerjaan dalam proses pemecahan masalah dari awal hingga selesai ketimbang tingkat deduksi informasi lakilaki serta mampu mengeksplor jawaban yang diinginkan dengan baik. Hal ini sesuai pada penelitian (Walia: 2012) bahwa peserta didik perempuan lebih unggul dalam memberikan ide-ide yang bervariasi

$$
\text { Hasil pemaparan proses }
$$
pemecahan masalah berdasarkan tingkat Van Hiele menyatakan adnya perbedaan antara subjek dalam proses pemecahan masalah. Hal ini berkaitan dengan penelitian dari Muhassanah, dkk (2014) yang menyatakan adanya perbedaan keterampilan yang dimiliki peserta didik berdasarkan tingkat berpikir Van Hieleny serta urutan tingkat berpikirnya. Abdussakir (2010) menyatakan peserta didik menganggap kebencian dalam mempelajari geometri dikarenakan geometri merupakan pelajaran yang sulit dipahami. Tujuan dalam mempelajari geometri ialah agar peserta didik dapat menyelesaikan pemecahan masalah dengan baik. Seperti yang diutarakan oleh Adolphus (2011) bahwa materi geometri dianggap sulit ditakuti yang menyebabkan tujuan penembangan kemampuan pemecahan masalah tidak tercapai.

Maka dari itu, perbaikan kualitas pembelajaran geometri dilakukan menggunakan teori Van Hiele melalui lima tahap pembelajaran:1) tahap informasi, yang mana guru bertugas menggali informasi sebnayak mungkin tentang kegiatan dan onjek-objek yang dipelajari pada tahap berpikir peserta dengan tanya jawab sambil melakukan observasi; 2) Tahap orientasi langsung, penggalian topik yang dipelajari melalui alat-alat yang cermat disiapkan guru oleh pserta didik; 3) Tahap penjelasan, mengemukakan pendapat mengenai struktur yang diobservasi oleh peserta didik; 4) Tahap orientasi bebas, mengerjakan tugas-tugas yang lebih komplek yang memerlukan banyak langkah, tugas yang dilengkapi dengan banyak cara dan tugas-tugas open ended yang dilakukan oleh siswa; 5) tahap integrasi, tinjauan kembali dan meringkas oleh peserta didik. Serta diakhir kegiatan pembelajaran adanya pengisian survey yang akan dilakukan oleh guru.

Adapun kualitas pengetahuan yang di miliki oleh peserta didik bukan merupakan hasil dari terhubungnya pengetahuan pengetahuan yang dimilikinya, melainkan dari adanya proses berpikir. Hal ini sejalan dengan penelitian Azimi dan Irawan (2012) yang menyatakan Peningkatan tahap berpikir siswa dari tahap visualisasi ke tahap analisis oleh penerapan pembelajaran geometri Van Hiele. Maka pembelajaran yang sesuai dengan tingkat berpikir peserta didik maka peserta didik dapat memecahkan masalah dengan baik.

\section{Kesimpulan dan Saran}

Adapun simpulan yang diperoleh adalah sebagai berikut:

1. Pada tahap visualisasi, peserta didik mampu mengidentifikasi masalah dan tujuan menggunakan bahasa soal, tetapi belum mampu dalam melaksanakan strategi maupun mengkaji kembali dan mengevaluasinya serta mencari strategi yang mungkin.

2. Tingkat berpikir Analisis, peserta didik mampu menacapai tahap pertama yaitu mengidentifikasi masalah dan tujuan menggunakan bahasa sendiri walaupun tidak sistematis, tahap kedua yaitu mampu mencari strategi yang mungkin, tahap ketiga yaitu melaksanakan strategi, walaupun tidak formal, tahap ke empat yaitu mengkaji kembali serta tahap kelima yaitu mengevaluasi. 
3. Pada tingkat deduksi informal, tercapainya tahapan satu hingga tahapan terakhir pemechan masalah dengan runtut dan sistematis.

Hasil penelitian ini diharapkan dapat memberikan sumbangan pemikiran sebagai usaha meningkatkan kemampuan dalam bidang pendidikan, khususnya bidang matematika. Saran yang dapat disampaikan penulis sehubungan dengan hasil penelitian ini adalah sebagai berikut.

1. Berdasarkan hasil proses pemecahan masalah geometri yang rendah maka guru perlu menerapkan pembelajaran geometri berdasarkan Van Hiele sehingga dengan konsep geometri yang matang diharapkan peserta didik dapat meningkatkan kemampuan dalam memecahkan masalah geometri.

2. Berdasarkan keterbatasan dari penelitian ini yang hanya menganalisis proses pemecahan masalah geometri pada tingkat visualisasi, analisis, dan deduksi informal maka diharapkan penelitian selanjutnya dilanjutkan untuk menganalisis proses pemecahan masalah geometri pada tingkat visualisasi, analisis, deduksi informal, deduksi formal dan rigor.

\section{Daftar Rujukan}

Abu, M. S. \& Abidin, Z. Z. (2013). Improving the Levels of Geometric Thinking of Secondary School Students Using Geometry Learning Video based on Van Hiele Theory. International Journal of Evaluation and Research in Education (IJERE). Vol. 2, No. 1

Abdussakir (2010). Pembelajaran Geometri Sesuai Teori Van Hiele. El-Hikmah: Jurnal Kependidikan dan Keagamaan . Vol VII Nomor 2, Januari 2010. ISSN 1693-1499.
Fakultas Tarbiyah UIN Maliki Malang. [Online].Tersedia: http:// abdussakir.wordpress.com. [20 Juni 2015]

Adolphus, T. (2011). Problems of teaching and learning of geometry in secondary schools in Rivers State, Nigeria. International Journal of Emerging Sciences, 1(2), 143-152.

Afrida, N., Hamam, P. A., \& Akbar, P. (2019). Implementasi Pendekatan Problem Solving Dengan Model Eliciting Activities Untuk Meningkatkan Kemampuan Berpikir Kritis Matematik Siswa SMP. Journal on Education, 1(4), 616-624.

Alex, J. K. \& Mammen, J. (2012). A Survey of South African Grade 10 Learners' Geometric Thinking Levels in Terms of the Van Hiele Theory. Anthropologist. Vol. 14. No. 2

Al-Migdady, A. M. (2014). SkilledUnskilled mathematical Problem Solvers: Jordanian-Students' Differences in Solving Geometrical Problems. European Scientific Journal. Vol. 10, No. 25 Aydoğdu, M. Z \& Keşan, C. (2014). A Research On Geometry Problem Solving Strategies Used By Elementary Mathematics Teacher Candidates. Journal of Educational and Instructional Studies. Vol. 4, No. 1

Azimi, S.N. dan Irawan, E.B. (2012). Upaya Meningktakan Tahap Berpikir Siswa pada Materi Garis Singgung Persekutuan Dua Lingkaran Melalui Pembelajaran Geometri Van Hiele Kelas VIII di MTs NW Lepak. Jurnal Pendidikan Matematika Universitas Negeri Malang [Online], Vol 1 (3). Tersedia: http://jurnal- 
online.um.ac.id/article/do/ detailarticle/1/31/1001 [17 Desember 2015].

Balitbang. (2012). Daya Serap Ujian Nasional Tahun 2012

Hasanah, M. (2013). Penerapan Tahapan Polya Berbasis Kooperatif untuk Meningkatkan Kemampuan Pemecahan Masalah Matematika pada Materi Aljabar Kelas XI IPA di SMAN 3 Malang. SKRIPSI Jurusan Matematika-Fakultas MIPA UM.

Khoiriyah, N, et al. (2013). Analisis Tingkat Berpikir Siswa Berdasarkan Teori Van Hiele Pada Materi Dimensi Tiga Ditinjau Dari Gaya Kognitif Field Dependent dan Field Independent. Jurnal Pendidikan Matematika Solusi. Vol. 1, No. 1

Muhassanah, N, et al. (2014). Analisis Keterampilan Geometri Siswa dalam Memecahkan Masalah Geometri Berdasarkan Tingkat Berpikir Van Hiele. Journal Elektronik Pembelajaran Matematika. Vol. 2, No. 1

NCTM. (2010). A Research on Geometry Problem Solving Strategies Used by Elementary Mathematics Teacher Candidates

Noriza, M. D., Kartono, K., \& Sugianto, S. (2015). Kemampuan Pemecahan Masalah dan Disposisi Matematis Siswa Kelas X pada Pembelajaran Berbasis Masalah. Unnes Journal of
Mathematics

Research, 4(2).

Özerem, A. (2012). Misconceptions In Geometry And Suggested Solutions For Seventh Grade Students. International Journal of New Trends in Arts, Sport \& Science Education. Vol. 1, No. 4

Pinar, A. (2014). Predictor Variables For Primary School Students Related To Van Hiele Geometric Thinking. Journal of Theory and Practice in Education. Vol. 10, No.1

Saragih, S \& Habeahan, W. L. (2014). The Improving of Problem Solving Ability and Students'Creativity Mathematical by Using Problem Based Learning in SMP Negeri 2 Siantar. Journal of Education and Practice. Vol. 5, No. 35

Sugiyono. (2016). Metode Penelitian Kuantitatif, Kualitatif dan R\&D. Bandung: PT Alfabet.

Walia, Pooja. 2012. Achievement In Relation to Mathematical Creativity of Eighth Grade Students. Indian Streams Research Journal Vol. 2, Issue.II /March; 12 pp. 1-4. [Online]. Tersedia: http://www.isrj.net. [diakses pada 4 Mei 2014].

Zhu, Z. 2007. Gender differences in matematical problem solving pattens: A review of literature. Internasional Education Journal, $8(2), 187-203$. 